\title{
THE PIRINEUS SYNTAXIS: AN EXAMPLE OF THE INTERSECTION OF TWO BRASILIANO FOLD-THRUST BELTS IN CENTRAL BRAZIL AND ITS IMPLICATIONS FOR THE TECTONIC EVOLUTION OF WESTERN GONDWANA
}

\author{
JOSÉ OSWALDO DE ARAÚJO FILHO
}

\begin{abstract}
The Pirineus Syntaxis (PSX) is a concave to the foreland (toward the craton) curve in the otherwise NS-trending structural grain of the orogenic province bordering the west side of the São Francisco craton. Its geometry reflects the intersection between two non-parallel foldthrust belts of different ages and style, formed during two separate non-coaxial deformation episodes during the Brasiliano Orogenic period of Neoproterozoic (probably around $900-600 \mathrm{Ma}$ ). These ages are not well constrained, since very little radiometric dating is available. The two limbs of the syntaxis are here interpreted as the younger and narrower Northern Brasília belt (NBB), and the older and more complete Southern Brasília belt (SBB). Rocks involved in the deformation that formed the PSX include the Paranoá, Canastra and Araxá Groups, generally accepted as passive margin environment and more restricted to the SBB. The Rio do Peixe Group is a volcanic-sedimentary sequence that prevalently occurs in the SBB, while the Intrusive Rock Suite and Related Metasedimentary Rocks predominantly occur in the NBB. The Granite-gneiss complex of the Goiás Massif (GCM) to the west, comprises the metamorphic core of the syntaxis. The collision of the Rio de la Plata (Paranapanema?) craton with the São Francisco craton formed the SBB, that preceded the final collision and accretion of the GCM with the SFC that formed the NBB. A weak collision of GCM with the southern border of the Amazonian craton determined the last deformation phase in the syntaxis. This is the first attempt to subdivide the Brasiliano of central Brazil and thus contributed to a better understanding of the evolution of western Gondwana. The conclusions of this paper were primarily based on field structural analysis.
\end{abstract}

Key words: Fold-thrust belt, Brasiliano orogeny, syntaxis, structural analysis, accreted terranes.

INTRODUCTION AND GEOLOGIC SETTING Curved foldthrust belts have been the subject of intense investigation (both field and laboratory studies) in the past fifteen years, with the purpose of elucidating their geometry, kinematics and evolution (e.g. Marshak 1988, Marshak and Flöttmann 1996; Marshak and Tabor 1989), Paulsen and Marshak (1994). Syntaxes are cusp forms or curves concave to the foreland (Sengör in Myashiro et al. 1988, Marshak 1988, Moores and Twiss 1995). The Pirineus Syntaxis (PSX) is a pronounced concave to the foreland curve in the otherwise north-south trending structural grain of the Brasília orogenic belt in Central Brazil. The PSX lies approximately between latitudes $15^{\circ} 40^{\prime} 00^{\prime \prime} \mathrm{S}$ and $16^{\circ}$ $00^{\prime} 00^{\prime} \mathrm{S}$ and longitudes $48^{\circ} 30^{\prime} 00^{\prime \prime} \mathrm{W}$ and $49^{\circ} 40^{\prime} 00^{\prime} \mathrm{S}$.

This structure was recognized since the first works of Ladeira et al (1963) and Almeida (1967). Broadly regional studies by Barbosa (1969), Costa and Angeiras (1970, 1971), Pena et al (1974) and Schobbenhaus Filho et al, (1975) were rather descriptive geometric studies of the syntaxis under various names such as "Pirenópolis structural feature", and "Pirineus Inflection". More recent studies investigated the origin, and detailed the kinematics of the PSX (Araújo Filho, 1978, 1980, 1981, 1992 a,b, Araújo Filho and Leonardos 1986 a, b, Araújo Filho and Faria 1992, Araújo Filho and Roscoe 1994, Fonseca 1996, Roscoe and Araújo Filho 1994, Strieder 1993). The study of the origin and evolution of the PSX, which bears implications to the evolution of western Gondwana, was presented by Araújo Filho and Marshak (1997), and Araújo Filho (1999 a, b).

Deformation in the Brasília belt has been attributed broadly to the Neoproterozoic Brasiliano orogeny. The syntaxis displays two limbs, the southern limb consisting of an east-verging fold-thrust belt in which spoon-shaped thrust sheets, bordered by lateral ramps, are arrayed in an imbricate fan. These thrust sheets consist of continental margin strata of the Araxá, Canastra and Paranoá Groups (Fig. 2). The Rio do Peixe Group of probable Paleoproterozoic age and convergent margin environment (back-arc ?) is tectonically imbricated with the Paranoá Group (Fig. 1). An east-west traverse across the southern limb passes through Barrovian-type metamorphic facies, from lower greenschist in the east to upper amphibolite in the west. Granulite-grade basement slices, locally retrograded to the amphibolite facies, derived from the Goiás Central Massif (Fig. 1), border the belt at its western margin. The northern limb of the syntaxis consists of a southsoutheast-verging fold-thrust belt. This belt consists of retrograded basement slices interleaved with basement-derived psammitic-pelitic schist. The Goianésia-Barro Alto mafic-ultramafic massif borders this belt to the north. Thrust faults parallel of those of the syntaxis's northern limb occur in the southern limb as well, where they cross-cut the east-verging structures of the southern limb. The two limbs have different structural and metamorphic histories. Subsequent to this history, the region was cut by $\sim \mathrm{NW}$-and NE-strike slip faults, perhaps during a late phase of the Brasiliano and finally by N-S strike JurassicCretaceous dikes.
ROCK UNITS OF THE PIRINEUS SYNTAXIS Rocks in the Pirineus Syntaxis (PSX) region range from possibly Archean to Quaternary in age. Most rocks in the area are Proterozoic (Figs. 1 and 2 ). The local stratigraphy of the PSX region cannot be defined using classical stratigraphic formalization used either in the North American Stratigraphic code or in the Brazilian Stratigraphic code, for rock sequences in the PSX region are not in conformable contact with each other. In fact, most contacts are shear zones and transposition during deformation has destroyed internal continuity of units. Tectonic group names of rock successions in the study area can be determined based on correlation with established regional stratigraphic columns in adjoining areas.

The summary description of rock units from the oldest to the newest is as follows:

Granulite Complex (AGC): also called Anápolis-Itauçú Granulite Complex (Almeida 1981, Marini et al 1984), which is has a debatable Brasiliano age (Pimentel et al 1991, Fuck et al 1994)and isotopically resettled during the Brasiliano orogeny (e.g. Marini et al. 1984, Radaelli 1994, Winge 1995, Fuck et al 1994). It occurs in the western and southwestern portion of the PSX and possibly consists of a collage of tectonostratigraphic terranes (island arcs and Archean rocks included) that were metamorphosed to the granulite facies, but locally have retrograded to the upper amphibolite facies. Two main rock associations, one mafic the other felsic, are distinguished. and composes the basement rocks of the study area. . The contact with younger and lower-grade rocks of distinct tectonic domains is an eastverging thrust.

Rio do Peixe Group (RPG): first defined by Araújo Filho (1981) and further detailed by Araújo Filho (1992, 1999), and CPRM (1994) as a Paleo/Mesoproterozoic volcanic-sedimentary sequence. This sequence was generated in an incipient oceanic crust environment, and outcrops as numerous tectonic slivers with younger rocks of the Araxá Group. This sequence consists of a lower unit of predominant mafic volcanics and an upper unit of terrigenous rocks and felsic volcaniclastics. The metamorphic condition is predominantly amphibolite facies, locally retrograded to epidote amphibolite (Fig. 2).

Araxá Group (PAG): composed of metasedimentary rocks in the study area, and tectonically imbricated with older rocks of the Rio do Peixe Group and younger units of the Proterozoic Intrusive and Related rocks, Canastra and Paranoá Groups. The PAG comprises two principal units, a lower Psammitic-pelitic Unit (PAGp) and an upper Pelitic-carbonate Unit (PAGc), imbricated by thrusting. Araxá rocks are in the upper greenschist/lower amphibolite facies transition and displays a weak progression of metamorphism from east to west (Fig. 1). Araújo Filho and Marshak (1997) and Araújo Filho (1999 a) proposed a passive margin basin environment for the Araxá Group in the study area.

Proterozoic Intrusive Bodies and Related rocks (PIB): This unit is an association of gneissic, mafic and ultramafic rocks of prevalent 


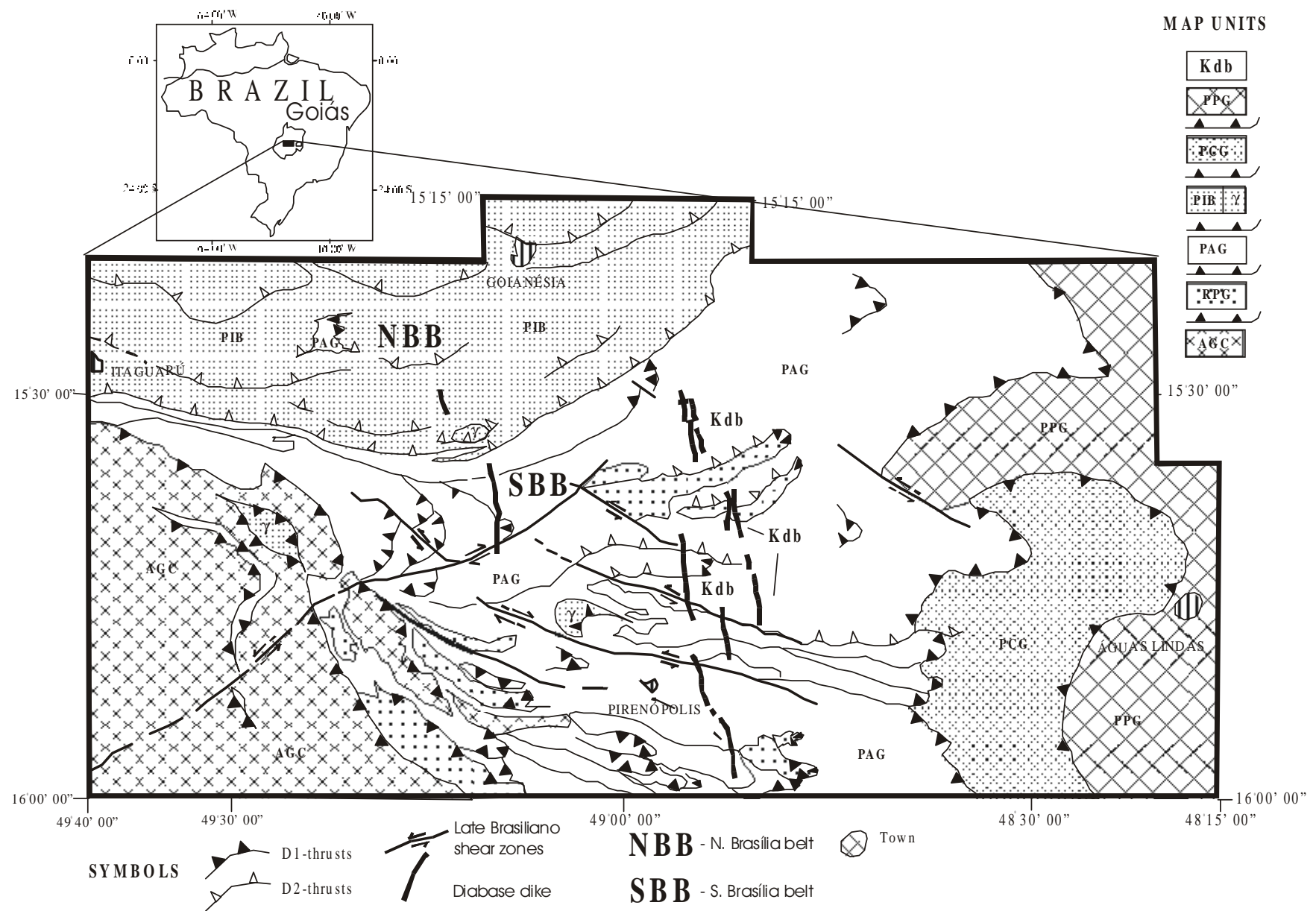

Figure 1-Location and simplified geologic map of the Pirineus Syntaxis, Central Brazil.

plutonic origin, with minor spatially associated plutonic and hypoabyssal rocks, plutonic-derived metasedimentary rocks and dynamically metamorphosed rocks. Main rock units are allochthonous rootless S- and A-type granitoids (greisen-bearing granitoids), talc schist, metarkose and feldspathic schist. These rock types are imbricated by thrusting, and older Araxá, Rio do Peixe and Granulite Complex rocks are in thrust contact with PIB. Mafic-ultramafic rocks rim the west border of the Granulite Complex and to a less extent, the southern border of the Goianésia Mafic-ultramafic Complex, and have a dominant talc schist composition with minor serpentinite. The maficultramafic rocks may represent relicts of a Brasiliano suture (Araújo Filho 1999, Marangoni 1994).

Canastra Group (PCG): it is composed essentially of phyllite and quartz phyllite in the study area, and is bound, by two major fault contacts. To the west, the Araxá Group has been thrust over the. PCG. To the east, the PCG has been thrust over rocks of the Paranoá Group (Figs. 1 and 2). The metamorphic grade is lower greenschist, and primary sedimentary structures can be identified. The PCG in the study area could be a marginal shallow marine facies of the Araxá Group.

Paranoá Group (PPG): in the study area the PPG is composed of a succession of metasedimentary rock types (from base to top, finegrained quartzite, metasiltstone, metarhythmite and metacarbonate). Primary sedimentary units are recognized and metamorphic grade is lower to sub-greenschist (anchimetamorphic conditions). The Paranoá in the area suggests deposits of a near shore portion of a shallow marine sedimentary basin and contains no rift-related sediments or volcanic interbeds.

Jurassic/Cretaceous dikes (Kdb): these rocks consist of unmetamorphosed diabase and fine-gabbro bodies that cross-cut all other rock units with exception of the Paranoá in the study area. The dikes have an average of $200 \mathrm{~m}$ width and extend up to $11 \mathrm{~km}$ in length, and form a series of vertical linear structures that preferentially strike NS to $\mathrm{N} 30^{\circ} \mathrm{W}$. An age of ( 130-60 Ma) is indicated by similar dikes dated in Maranhão and Paraná basins in Brazil (Marini et al. 1984, DNPM/CPRM, 1994), and probably represent a relict of crustal

\begin{tabular}{|c|c|c|c|c|c|}
\hline EON & ERA & \multicolumn{2}{|l|}{$\begin{array}{l}\text { UNIT } \\
\text { NAME }\end{array}$} & \begin{tabular}{|l|} 
BRIEF ROCK - \\
TYPE DESCRIPTION \\
\end{tabular} & \begin{tabular}{|l|} 
MAP \\
SYMBOI \\
\end{tabular} \\
\hline $\begin{array}{l}\text { PHANERO- } \\
\text { ZOIC }\end{array}$ & $\begin{array}{l}\text { MESO- } \\
\text { ZOIC }\end{array}$ & \multicolumn{2}{|l|}{ Dikes } & \begin{tabular}{|l|} 
diabase and fine- \\
grained gabbro dikes \\
\end{tabular} & $\mathrm{Kdb}$ \\
\hline & U & \multicolumn{2}{|c|}{$\begin{array}{l}\text { Paranoá } \\
\text { Group }\end{array}$} & $\begin{array}{l}\text { me tapelite and } \\
\text { metacarbonate }\end{array}$ & PPG \\
\hline & $\begin{array}{l}O \\
N \\
O\end{array}$ & \multicolumn{2}{|c|}{$\begin{array}{l}\text { Canastra } \\
\text { Group }\end{array}$} & metapelite & PCG \\
\hline $\begin{array}{c}\sim \\
\mathrm{N} \\
\mathrm{N}\end{array}$ & 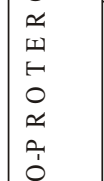 & \multicolumn{2}{|c|}{$\begin{array}{l}\text { Intru sive } \\
\text { Sequence } \\
\text { and } \\
\text { related } \\
\text { rocks }\end{array}$} & $\begin{array}{l}\text { two-mica meta } \\
\text { granitoid with greisen }(\gamma) ; \\
\text { alpinotype volcanics; } \\
\text { feldspathic schist } \\
\text { and metarkose }\end{array}$ & \begin{tabular}{l|l|} 
PIB & $\gamma$ \\
\end{tabular} \\
\hline $\begin{array}{l}0 \\
\simeq\end{array}$ & $\begin{array}{l}\text { W } \\
\text { ż } \\
\text { in }\end{array}$ & \multirow{2}{*}{ 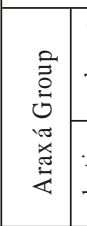 } & 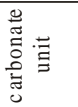 & $\begin{array}{l}\text { Metacarbonate } \\
\text { and metacalc- } \\
\text { silicate rocks }\end{array}$ & PCGc \\
\hline E & 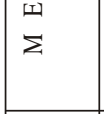 & & 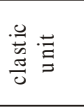 & $\begin{array}{l}\text { metapelite } \\
\text { metapsammite } \\
\text { metaconglomerate }\end{array}$ & PCGp \\
\hline \multirow[t]{2}{*}{ a } & 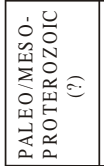 & \multicolumn{2}{|c|}{ 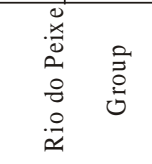 } & $\begin{array}{l}\text { Volcanic-sedimentary } \\
\text { sequence }\end{array}$ & RPG \\
\hline & 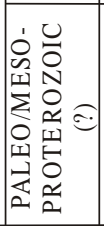 & 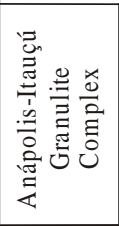 & 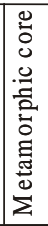 & $\begin{array}{l}\text { felsic and mafic } \\
\text { granulite, possibly } \\
\text { derived from } \\
\text { TTG-terranes }\end{array}$ & $\mathrm{AGC}$ \\
\hline
\end{tabular}

Figure 2-Simplified description of map unit of the Pirineus Syntaxis, Central Brazil. 
extension that affected the eastern and central portions of the South American plate, resulting in the opening of the South Atlantic Ocean.

STRUCTURAL ANALYSIS The PSX includes a portion of the Brasília fold-thrust belt, here divided into a northern and a southern segment, as well as a portion of the Goiás Massif, a microplate, possibly resulted from the collage of tectono-stratigraphic terranes that includes the Anápolis-Itauçú Granulite Complex (Pimentel et al. 1999).

From east to west, in rocks of the southern limb of the syntaxis (predominantly Paranoá, Canastra, Araxá, and Rio do Peixe Groups) there is a progressive change in the type of fabric, defining a gradient, from less penetrative spaced cleavage (in rocks of Paranoá and Canastra Groups) to more penetrative axial surface foliation in folds and transposed foliations in shear zones in rocks of the Araxá and Rio do Peixe Groups (Fig. 1). In gneiss and migmatite of the metamorphic core, in the domain of the Goiás Central Massif, to the west of the study area, flow folds predominate. Form lineations (fold hinges of mesoscopic and microscopic folds, crenulations, rodding, mullions, elongated deformed pebbles and boudins), surface lineations (intersection lineations and slip lineations - mainly mineral fibers) and mineral lineations (elongated and stretched grains, microscopic pressure shadows in low grade metamorphic rocks and local mineral fibers) have about the same trend (vary from $\sim 05^{\circ}-35^{\circ} ; 265^{\circ}-280^{\circ}$, a dispersion angle of $\sim 15^{\circ}$ ) in rocks of the Paranoá, Canastra, Araxá and Rio do Peixe in the southern limb of the syntaxis. In the northern limb of the syntaxis, where Proterozoic Intrusive and Related Rocks (PIB) predominate, schistosity and mylonitic foliation are the dominant planar fabric. Schistosity parallels the axial surfaces of large S-SE-verging folds and locally cross cuts previous foliation (either previous schistosity or mylonitic foliation) and forms a crenulation. Mylonitic foliation is a more intense foliation, not related to axial surface foliation and contains retrometmorphic minerals in fine-grained felsic gneiss. Form lineations (mainly mesoscopic and microscopic fold hinges and stretched pebbles), surface lineations and mineral lineations display a broader angle of dispersion $\left(\sim 50^{\circ}\right)$, varying from $\sim 5^{\circ}-40^{\circ}$; $15^{\circ}-295^{\circ}$.

Based on cross-cutting relations, we can recognize three generations of foliations in the study area $\left(\mathrm{S}_{1} ; \mathrm{S}_{2}\right.$ and $\mathrm{S}_{3}$ from oldest to youngest). $S_{1}$ is predominant in the southern limb of the syntaxis, and only locally occurs in the northern limb (Fig.1). $\mathrm{S}_{2}$ predominantly occurs in the northern limb and, largely, generates the crenulation foliations in the southern limb $\left(S_{2}\right.$ overprints $\left.S_{1}\right) . S_{3}$ is prevalently a disjuncive spaced foliation associated with upright open to closed folds that occurs both in the northern and the southern limb of the syntaxis. Locally, $\mathrm{S}_{3}$ crenulates both $\mathrm{S}_{1}$ and $\mathrm{S}_{2}$.

Interformational and intraformational shear zones (both mesoscopic and regional) characterize shallow-dipping $\left(<25^{\circ}\right)$ to steep-dipping $\left(>50^{\circ}\right)$ ductile shear zones in the study area. In the southern limb (Fig.1), kinematic indicators such as western-dipping mylonitic foliation, curving traces convex toward the east, preponderantly easterly verging parasitic folds; C-S fabric in mylonites, and mica-fish in mylonitic muscovite quartzite, confirm that shear zones transported rocks eastward. In the northern limb of the PSX, thrust shear zones verge toward the $\mathrm{S}$ - to $\mathrm{SE}$, observing the same types of kinematic indicators. Stretched pebbles and quartz veins serve as good strain markers in the shear zones. Deformed pebbles of metaconglomerate and stretched veins in muscovite-quartzite of the Araxá Group indicate preferential distribution in the field of constriction in Flinn diagrams.

Mesoscopic folds (outcrop scale) are generally tight to isoclinal, and verge toward the E in the southern limb and toward the S-SE in the northern limb of the PSX. Mesoscopic folds locally grade into sheath folds in high-strain environments in the southern limb. Mesoscopic folds display an easterly-vergence gradient from weak to strong from east to west in the southern limb. Open upright folds constitute another set of folds locally seen in both limbs in the study area, with only very weak easterly vergence in central-western portions of the southern limb. Regional-scale folds (they range from hundreds of meters to a few kilometers in dimension) are more frequent in the southern limb, are generally intraformational and easterly-verging. Those few that occur in the northern limb are S-SE-verging. Complex disharmonic folds are the predominant geometry of the high grade rocks of the Granite-gneiss Complex (part of Goiás Massif). Passive and nonpassive folds (flexural-slip; flexural flow and buckle folds) are the two basic kinds of folds in the study area. Passive folds are dominant in the high-grade gneiss, migmatite and associated amphibolite and schist of the Goiás Massif. They display a Class 2 and 3 isogonic geometry and their geometry suggests that they were formed by a uniform flow of the entire rock mass, with layering not taking active part in controlling fold shape. In low greenschist conditions of the southern limb, flexural-slip folds predominate. Class $1 \mathrm{~B}$ folds imply a mechanism compatible with maintaining constant layer thickness during folding, with the implication that friction between layers was relatively low, allowing them to slide one past the other. Class $1 \mathrm{C}$ folds would require a minor contribution of flexural flow, or a higher than usual competence contrast between layers. Flexural-flow is the dominant mechanism for fold formation in the central region of the southern limb and in the northern limb of the syntaxis. Most of flexural-flow folds display thickening of fold hinges (Classes 1C and 3) and the style is compatible with medium greenschist/low amphibolite grade of the rocks involved in folding. At such metamorphic conditions, mean ductility range from moderate to high (Donath and Parker 1964). Buckle folds occur in migmatite and high-grade gneiss in the western portion of the study area and display a regular wavelength and uniform amplitude and involve more competent quartz-feldspathic layers, imbedded in weak rocks.

Joints are the most important fractures in the study area, and occur both in the mesoscopic and regional scales, the latter reaching a maximum trace of $45 \mathrm{~km}$. Joints are predominantly vertical and define two mutual orthogonal sets $\left(\mathrm{N} 05^{\circ} \mathrm{E}-\mathrm{N} 10^{\circ} \mathrm{W}\right.$ and $\left.\mathrm{N} 85^{\circ} \mathrm{E}-\mathrm{N} 80^{\circ} \mathrm{W}\right)$. Rose diagrams indicate a higher frequency of NS-joints than EWjoints in all map scales. These joint sets display a mixed pattern of both ladder and grid types, which suggest that they might have been formed at the same time. Joints cross-cut all other structures in both limbs of the syntaxis and also in rocks of the Granite-gneiss Complex to the west, and thus constitute the youngest structures of the study area. Veins, generally quartz filled, and locally mineralized in gold and in cassiterite (the latter related to A-type granitoids), are largely filling mesoscopic joints. There are a minimum of two generations of veins, one related with the emplacement of granitoid bodies and the other related to the formation of shear zones during the Brasiliano deformation. Brittle mesoscopic faults occur only locally in the study area. They parallel major joint sets. The fault surfaces are recognized by the presence of slickensides, silica enrichment and cataclasite. Fault surfaces are steeply-dipping $\left(>70^{\circ}\right)$ and erosion controlled by these faults yields fault line scarps, along which most of the waterfalls in the region occur.

\section{A TECTONIC MODEL FOR THE PIRINEUS SYNTAXIS}

Previous studies of the PSX considered the syntaxis to lie within a single orogen. In single orogenic models, the syntaxis could be due to an eastward propagating fold-thrust belt with a basement high, much like the Uinta Recess formed as a result of the intersection between the Sevier fold-thrust belt in the western USA cordillera (Paulsen and Marshak in preparation). This model would require continuity between the two limbs of the syntaxis. However, my results indicate that the PSX actually lies at the intersection of two separate fold-thrust belts. Therefore, I suggested the names Northern Brasília belt (NBB) for the northern limb, and Southern Brasília belt (SBB) for the southern limb of the syntaxis. I also suggest that the PSX simply reflects the intersection of two non-coaxial, non-coeval belts (the S-SE-verging NBB being younger than the E-verging SBB). The SBB contains typical metamorphic/deformational domains of a fold belt, namely the external, transitional and internal zones (with a gradient towards the west from low grade metamorphic conditions/less deformed rocks to intermediate-high grade metamorphic conditions/more deformed rocks, reaching intense thrusting and strong transposition). The SBB consists of a series of thin-skinned thrusts with predominantly easterly vergence (Fig. 1). The NBB is a narrower ( $32 \mathrm{~km}$ across) and less complete fold-thrust belt than the SBB. The NBB forms an antitaxial curve convex to the SE and mineral lineations, fold and thrust vergences indicate tectonic transport to the $S$ and SE. The NBB consists of a series of parallel imbricate thrusts, without associated sheath-like fold geometries (Fig. 1). This geometry suggests that the NBB formed under less ductile conditions. Further, because high grade crystalline rocks occur in the thrust slices, I conclude that the detachment surface is at depth within the basement, and that basementpenetrating faults were inverted. 
If the SBB and NBB are indeed separate, and if they have different kinematics, then there should be evidence of overprinting. Numerous examples of fold-interference structures are found in the syntaxis, especially in the SBB. Where distinct fold generation can be deciphered, $F_{3}$-folds overprint $F_{2}$-folds and $F_{2}$-folds overprint $F_{1}$-folds. $\mathrm{F}_{1}$-folds are east-verging, generally NS-trending isoclinal folds and minor open asymmetrical and, locally, symmetrical folds; $\mathrm{F}_{2}$-folds are $\mathrm{S}$-SE-verging, EW-trending, tight to isoclinal folds and $\mathrm{F}_{3}$-folds are gentle to open, EW-trending folds. The superposition of $\mathrm{F}_{2}$-folds on $\mathrm{F}_{1}$-folds generally produces a fold-interference pattern close to Type 2 or a hybrid type between 1 and 2 . In the central and eastern portions of the PSX, $\mathrm{F}_{3}$-folds and $\mathrm{F}_{1}$-folds produce Type 1 ("dome and basin") interference pattern. Superposition of $F_{3}$-fold with $F_{1}$-fold is not clearly defined in the study area. Superposition of $\mathrm{F}_{3}$-folds with $\mathrm{F}_{-}$ folds generates a Type 3 "zigzag" fold-interference pattern. Further, examination of polyphase fabric demonstrates that the three phases of foliation $\left(\mathrm{S}_{1}, \mathrm{~S}_{2}\right.$ and $\left.\mathrm{S}_{3}\right)$ are respectively related to the three type of folds $\left(F_{1}, F_{2}\right.$ and $\left.F_{3}\right)$. Because of the occurrence of distinct sets of folds and fabric, I recognize three main phases of deformation $-D_{,}, D_{2}$ and $D_{3}$. $D_{1}$ is related to a the major episode of the formation of the SBB. $\mathrm{D}_{2}$ is related to the compressional deformation of the NBB and $\mathrm{D}_{3}$ is possibly related to a weaker pulse of deformation that affected the two belts after their generation. A phase that formed ENE and WNWtrending, tardi-Brasiliano ductile-brittle shear zones is identified as $\mathrm{D}_{4}$. A late extensional phase that yielded diabase dikes in the Jurassic/ Cretaceous is $\mathrm{D}_{5}$, with evidences of later reactivation as joint sets and local normal faults.

\section{IMPLICATIONS FOR THE EVOLUTION OF WESTERN}

GONDWANA Compressional tectonism occurred to the south of the PSX to form the SBB, prior to compression in the north, to form the NBB. But what are the pieces that collided? The development of the Brasília belts along the western margin of the São Francisco craton likely involved the interaction between the São Francisco craton, the Goiás Massif, the Rio de la Plata craton (or possibly the Paranapanema craton, a northern to the Rio de la Plata smaller craton, under the Paraná Basin, delineated solely on geophysical data, Brito Neves B.B) and the Amazonian craton. Specifically, the formation of the SBB might represent the collision between the Rio de la Plata (Paranapanema?) craton. and the São Francisco craton, which continued until peak metamorphic conditions were reached at $\sim 0.6 \mathrm{Ga}$. This collision caused the inversion of the Araxá/Paranoá rocks (both of a passive margin signature in the study area), resulting in the formation of an E-verging fold-thrust belt ( $\mathrm{D}_{1}$-episode). Later accretions and collision of the GCM and the SFC in the Brasiliano, suggests the formation of the NBB. This $\mathrm{D}_{2}$-compressional episode generated a NNW-SSE shortening. A possible late accretion phase of the GCM, resulting from a weak collision with the Amazonian craton, may have caused the $\mathrm{D}_{3}$-comperssional phase (Fig. 3). Thus, this implies that the
Brasiliano orogeny in central Brazil is not undivided, as previously considered, but that can be rather subdivided into, at least, two episodes of deformation. Likely, the Pan-African of Africa, is further subdivided today (e.g., Clifford 1970, Jackson and Ramsay 1980, Kröner 1980, Trompette 1994, Unrug 1997). Recent isotopic data may support evidences of terrane accretion in high grade rocks to the $\mathrm{W}$ and SW of the study area in the Goiás Massif, that may also be true for Araxá rocks (Pimentel et al. 1999). Therefore, the main compressional deformation events in the study area ultimately resulted from the convergence of the São Francisco, Rio de la Plata (Paranapanema?) and Amazonian cratons during the Brasiliano, and contributed to the assembly of Western Gondwana.

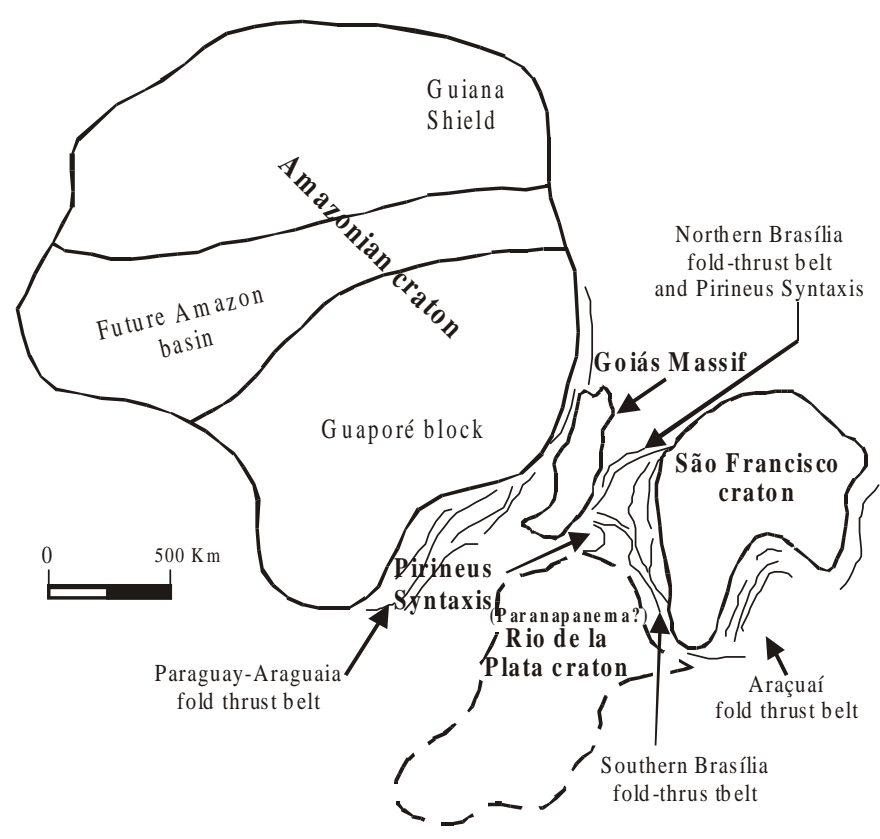

Figure. 3-Model of the formation of the Northern Brasilia belt (NBB) and Southern Brasilia belt $(S B B)$. Inverted tectonic regime begins to form the $S B B$ ( $D_{1}$-deformation), as a result of the convergence of the Rio de la Plata (Paranapanema?) and São Francisco (SFC) cratons. Formation of the NBB was due to the collision between the Goiás Massif and the SFC, possibly beginning $\sim 600 \mathrm{Ma}\left(\mathrm{D}_{2}\right.$-deformation $)$. An interpreted weak collision between the NW-tip of the Goiás Central Massif with the Amazonian craton, generated the $D_{3}$-deformation. Ultimately, the PSX resulted in the interaction of three cratonic blocks and a microplate.

\section{References}

Almeida F F M de. 1967. Nota sobre o Pré-Cambriano na região central de Goiás. Bol. Paranaense de Geociências, 26:19-22.

Araújo Filho J O de. 1978. The Geology of Pirenópolis- Corumbá de Goiás, central Brazil. In: Geowibenchaftliches Lateinamerika Kolloquium, 6, Kurzfassungen, 7-8 Stuttgart.

Araújo Filho J O de. 1980. The geology of the Pirineus Megainflection, Goiás, Central Brazil. In: Geowibenschaftliches Lateinamerika Kolloquium, 7, Kurzfassungen, 9 11. Heidelberg.

Araújo Filho J O de. 1981. Contribuição à estratigrafia e tectônica da Megainflexão dos Pirineus. In: SBG, Simpósio de Geologia do Centro Oeste, 1, 24-26. Goiânia.

Araújo Filho J O de. 1992 a. A estrutura do granitóide de Fazenda Raizama: um exemplo de uma mega dobra-em bainha na Mega-Inflexão dos Pirineus. IG/UnB, Simp. de Geociências do IG, 1, 1:17

Araújo Filho J O de. 1992 b. The Pirineus Megainflection in central Brazil: an example of a poly-deformed Brasiliano fold-thrust belt. In: Geowibenshaftliches Lateinamerika Kolloquium, 13, Kurzfassungen, 18-19. Münster.

Araújo Filho J.O de. 1999 a. Structural characteristics and tectonic evolution of the Pirineus Syntaxis, Central Brazil. University of Illinois at Urbana-Champaign, USA, Ph.D. Thesis, $433 \mathrm{p}$.

Araújo Filho J.O. de. 1999 b. A Sintaxe dos Pirineus: um exemplo de dois cinturões Brasilianos no centro oeste do Brasil. In: SBG, Simpósio de Geologia do CentroOeste; 7, Simpósio de Geologia de Minas Gerais, 10, Boletim de Resumos, 79.

Araújo Filho J.O \& Faria A de. 1992. Características estruturais da propagação do Canastra sobre o Paranoá no evento Brasiliano do Distrito Federal. In: Congr. Bras. Geol, 37, Bol. Resumos Expandidos, 319-320, São Paulo.

Araújo Filho J. O de \& Leonardos O.H. 1986. A esmeralda do município de Pirenópolis: um exemplo de greisenização de talco-xistos. In: SBG, Congr. Bras. Geol., 34, Anais 4:1835- 1845 .
Araújo Filho J O de \& Roscoe J S. 1994. A redefinição tectono-estratigráfica e a cinemática do cavalgamento Araxá/Paranoá na porção oriental da Megainflexão dos Pirineus. In: SBG, Congr. Bras. Geol., 38, Camboriu, Anais, 290-292.

Araújo Filho J. O de \& Marshak S. 1997. Formation of the Pirineus Syntaxis: evidence for two episodes of Brasiliano (Pan African) deformation in the Brasília Orogenic Belt, Central Brazil. GSA Abstract with Programs A-228, BTH 44, Salt Lake City.

Barbosa O, Batista M.B, Dyer R; Braun O. P.G, Cotta J.C. 1969. Projeto Brasília- Goiás. Geologia e inventário dos recursos minerais. PROSPEC/DNPM, Goiânia, 225 pp. Unpublished.

Clifford T.N. 1970. The structural framework of Africa. In: T.N. Clilfford \& I.G. Gass (eds) African magmatism and tectonics. Oliver \& Boyd, 1-26.

Costa L.A.M. \& Angeiras A.G. 1970. Tectonic zoning in the Epi-Baikalian platform of Central Brazil. Anais da Academia Brasileira de Ciências, 41:1034-1050.

Costa L.A.M. \& Angeiras A.G. 1971. Geosynclinal evolution in the Epi-Baikalian platform of Central Brazil. Geol. Rundschau, 60(2):1024-1050.

DNPM/CPRM. 1994. Pirenópolis, Folha SD-22-Z-D-V, Estado de Goiás, Texto Explicativo. Programa de Levantamentos Geológicos Básicos do Brasil, 108p

Donath F.A. \& Parker R.B. 1964. Folds and folding. Geological Society of America Bulletin, 75:45-62.

Fonseca M A. 1996. Estilos estruturais e o arcabouço tectônico do segmento setentrional da Faixa Brasília. Universidade de Brasília, Doctoral Thesis.

Fuck R A., Pimentel M.M., D’el-Rey Silva L.J.H. 1994. Compartimentação tectônica na porção ocidental da Província Tocantins. In: SBG, Congr. Bras. Geol., 38, Bol. Resumos Expandidos, 1:215-216.

Jackson N.J. and Ramsay C.R. 1980. What is the "Pan-African"? A consensus is needed. Geology, 5:210-211. 
Kröner A. 1980. Pan-african crustal evolution. Episodes, 2:3-8.

Ladeira E.A., Ribeiro C.L., Godoy A.C. Fleury, J. N. 1963. Contribuição à geologia de Pirenópolis, Goiás. Revista. da Escola de Minas, Ouro Preto, 22(5)

Marangoni Y.R. 1994. Modelo crustal para o norte de Goiás a partir de dados gravimétricos. IAG/USP, Doctoral Thesis.

Marini O.J., Fuck R.A., Danni J.C.M., Dardenne M.A. 1984. A província Tocantins no Brasil Central. In: F.F.M. de Almeida \& Y. Hasui (eds), O Pré-Cambriano do Brasil. Ed. Edgar Blücher, São Paulo, 484 p.

Marshak S. 1988. Kinematics of oroclines and arc formation in thin-skinned orogens Tectonics, 7(1):73-86.

Marshak S. \& Flöttmann T. 1996. Structure and origin of the Fleurieu and Nackara Arcs in the Adelaide fold-thrust belt, South Australia. Jour. of Structural Geology, 18(7):891-908.

Marshak S. \& Tabor J.R. 1989. Structure of the Kingston Orocline in the Appalachian foldthrust belt, New York. GSA Bulletin, 101:683-701.

Moores E \& Twiss R.J. 1986. Tectonics. Ch. 13. W.H. Freeman and Co., New York, 415

pp.
Paulsen T. \& Marshak S. 1994. Structure of the Charleston traverse zone, Wasatch Mountains, Utah: strike-slip deformation during formation of a map view curve in the Sevier fold-thrust belt. GSA Abstract with Programs.

Paulsen T. \& Marshak S. Origin of the Uinta Recess in the Sevier fold-thrust belt, Utah: a consequence of Pre-Sevier basin architecture. In preparation.
Pimentel M.M, Fuck R.A., Fischel D.P. 1999. Estudo isotópico Sm-Nd regional da porção central da Faixa Brasília, Goiás: implicações para a idade e origem dos granulitos do complexo Ánápolis-Itauçú e rochas metasedimentgares do Grupo Araxá. Rev. Bras. Geoc., 29(2):271-276.

Roscoe J. S. \& Araújo Filho J.O. de. 1994. Estudo estrutural preliminar do front do empurrão do Araxá sobre o Paranoá na porção oriental da Megainflexão dos Pirineus, Goiás central. In: SBG, Simp de Geologia do Centro-Oeste, 4 Brasília, 177-179

Sengör A M.C. in Miyashiro A, Aki, Sengör, A M.C. 1982. Orogeny. Ch. 1, John Wiley and Sons, Chichester.

Schobbenhaus C., Campos D. de A., Derze G.E., Asmus H. E. 1984. Geologia do Brasil texto explicativo do Mapa Geológico do Brasil e da área oceânica adjacente incluindo depósitos minerais. DNPM, 501pp. Brasília.

Trompette R. 1994. Geology of western Gondwana (2,000-500 Ma). A. A. Balkema. Rotterdam, $350 \mathrm{pp}$.

Unrug R. 1997. Rodinia to Gondwana: the geodynamic map of Gondwana supercontinent assembly. GSA Today, 7(1):1-6.

Contribution IGC-159

Received February 2, 2000 Accepted for publication April 30, 2000 